\title{
Collegia through their funeral activities: new light on sociability in the early Roman Empire
}

\author{
Los collegia a través de sus actividades funerarias: \\ nuevas luces sobre la sociedad en el Alto Imperio Romano
}

\author{
Mitsuyoshi SANO*
}

\section{RESUMEN}

En este artículo, entre las actividades que los collegia realizaron en la Roma altoimperial me concentro en las funerarias habiendo realizado un análisis exhaustivo de las inscripciones relacionadas con las actividades funerarias de los collegia y considerado qué tipo de gente se unió a cada collegium y las que fueron sus principales motivaciones. En cuanto al estado o extracción de sus miembros, podemos estar seguros que entre sus miembros tuvo un cierto protagonismo la población que era originaria de las provincias orientales y de extracción servil, representando aquélla, aproximadamente, el $70 \%$ de todos los miembros de collegia. En cuanto al significado de collegia para sus miembros podemos concluir que los collegia ofrecían a sus miembros posibilidades de obtener relaciones casi de patrón familiar.

PALABRAS CLAVE

Historia social romana, sociabilidad, mentalidad, collegia, asociaciones voluntarias, familia romana.

\begin{abstract}
In this article, I focus on funeral activities from among the many activities that the collegia performed. I have made an exhaustive analysis of the inscriptions concerned with the funeral activities of collegia and thus considered what kind of people gathered in collegia and why they did so. Regarding the status or origin of members, we can be fairly certain that the people coming from the East and people who had formerly been slaves or were close offspring of slaves accounted for about $70 \%$ of all the members of collegia. As to the significance of collegia for the members, we can conclude that collegia became the means by which members could obtain quasi-family relationships.
\end{abstract}

\section{KEYWORDS}

Roman social history, sociability, mentality, collegia, voluntary associations, Roman family.

Recibido el 30 de mayo de 2012. Aceptado el 27 de junio de 2012

* Kyoto Women's University, Japan. 8-507, Takehanasotodacho, Yamashina-ku, Kyoto, 607-8081 JAPAN: acca_h@livedoor.com 


\section{INTRODUCTION}

It is almost impossible for us to know what exactly the lives of ordinary people were like in the Roman Empire, except perhaps for those preserved under exceptional circumstances, such as in Pompeii. However, the relationships that ordinary people established among themselves, the role that such relationships played in Roman society, and the mentality (i.e., mentalité) that operated in those relationships are certainly pertinent to Roman social history.

One of the ways of addressing this issue is to use inscriptions on tombstones, which have been found in huge quantities throughout the empire. For example, using tombstones, Saller and Shaw showed that most households in republican Rome already consisted of nuclear families. In doing so, they challenged the theory based on legal sources that Roman households were composed of complex, extended families and also the theory based on literary sources that households became nuclear ones during the age of Augustus ${ }^{1}$. Research through tombstones has helped us to understand Roman society. However, it has its limits, as many scholars have pointed out: first, the image of a family that we can identify from inscriptions is a portrait at the time of the death of a family member; second, we can analyze only the relationship between the dead and his or her nearest relatives.

Should such constraints with the historical materials oblige us to abandon efforts to understand the sociability (i.e., sociabilité) among ordinary people in the empire or their mentality? There is in fact one subject area that allows us to examine the sociability and mentality of ordinary people living in cities and towns in those times. That subject area is social groups-collegia-which were active in the early Roman Empire. Collegia were voluntary associations and involved people getting together in professional or religious bonds in cities and towns. The present paper examines these social groups and how they shed new light on sociability in the early Roman Empire.

The area investigated in this paper is the western part of the empire: from Dacia and Moesia in the east to the Iberian Peninsula in the west; from Britannia in the north to the western half of North Africa in the south. This area was chosen because in the eastern part of the empire, especially in Greece, there was a tradition of voluntary associations that differed from those in the western part ${ }^{2}$. The period covered in this paper is the time of the early empire, when collegia were most active. Though this time span appears to be rather long, few inscriptions can be dated precisely, and so arguing using only such inscriptions would not be productive in the present case.

1 SALLER, R. P. \& SHAW, B. D., "Tombstones and Roman Family Relations in the Principate: Civilians, Soldiers and Slaves", JRS, 74, (1984), pp. 124-156; SHAW, B. D., "Latin Funerary Epigraphy and Family Life in the Later Roman Empire", Historia, 33, (1984), pp. 457-497.

2 Dig., XLVII, 22, 4; VAN NIJF, O. M., The Civic World of Professional Associations in the Roman East, Amsterdam, Brill, 1997, p.24. 


\section{OVERVIEW OF PREVIOUS RESEARCH AND PURPOSE OF THIS PAPER}

A good deal of research has built up on the whole study on collegia. Efforts began with the dissertation by Mommsen ${ }^{3}$, and some recent papers and monographs have been published on the topic. In this section, I will present an overview of previous studies on collegia and clarify the area of focus of the present paper.

What kind of groups were collegia? They are now generally recognized as follows. In Roman society, some artisans or merchants got together according to their professions. There also appeared social groups of people sharing a faith in particular deities and as well as burial societies (so-called collegia funeraticia), in which members assembled to make funeral arrangements for their dead associates. All of these were referred to as collegia. From the end of the republic, their activities were clearly recognized ${ }^{4}$. As Rome was being imperialized, probably Caesar or Augustus passed a law permitting collegia to be established. However, it appears that people were actually free to form collegia ${ }^{5}$. As well as ordinary citizens, slaves were able to take part in collegia if their masters allowed them to do $\mathrm{so}^{6}$. Collegia were thus voluntary and private associations ${ }^{7}$. They were less concerned with political or economic activities ${ }^{8}$ but served for pleasure and mutual support among their members. Members of collegia derived a basis for social activities and identity ${ }^{9}$.

This commonly accepted theory is founded on the works of Mommsen and Waltzing ${ }^{10}$. Waltzing compiled all the inscriptions he used in his monumental book,

${ }^{3}$ MOMMSEN, Th., De Collegiis et Sodaliciis Romanorum, Kiliae, 1843.

${ }^{4}$ During the Roman Kingdom: Plut., Vit. Num., 17; GABBA, E., "The Collegia of Numa: Problems of Method and Political Ideas", JRS, 74, (1984), pp. 81-86.

${ }^{5}$ On the governmental attitudes towards collegia: COTTER, W., "The Collegia and Roman Law", in: KLOPPENBORG, J. S. \& WILSON, S. G.(eds.), Voluntary Associations in the Graeco-Roman World, London \& New York, Routledge, 1996, pp.74-89. Cf. DE LIGT, L., "Governmental Attitudes towards Markets and Collegia", in: LO CASCIO, E.(ed.), Mercati permanenti e mercati periodici nel mondo romano, Bari, Edipuglia, 2000, pp.237-252; DE LIGT, L., "D. 47, 22, 1, pr.-1 and the Formation of Semi-Public Collegia", Latomus, 60-2, (2001), pp.345-358; ARNAOUTOGLOU, I. N., "Roman Law and Collegia in Asia Minor", RIDA, 49, (2002), pp.27-44; ARNAOUTOGLOU, I. N., "Collegia in the Province of Egypt in the First Century AD", Ancient Society, 35, (2005), pp.197-216; LIU, Jinyu, "Local Governments and Collegia: a new appraisal of the evidence", in: AUBERT, J.-J. \& VARHELVI, Z.(eds.), A Tall Order: Writing the Social History of the Ancient World, Essays in Honor of William V. Harris, München, K. G. Saur Verlag, 2005, pp. 279-310.

${ }^{6}$ Dig., XLVII, 22, 3.

${ }^{7}$ On the other hand, some collegia were connected with the government. For example, the government encouraged people to join the collegia that contributed to public utilities by granting them the privilege of immunity from some obligations to cities (Dig., L, 6, 6.).

${ }^{8}$ Political activity of collegia is thought to be done through the patrons of collegia: CLEMENTE, G., "II patronato nei collegia dell'impero romano", SCO, 21, (1972), pp. 142-229.

9 WALTZING, J.-P., Étude historique sur les corporations professionnelles chez les romains, 4 tomes, Louvain, C. Peeters, 1895-1900, I, p. 332. (hereafter, Étude)

10 WALTZING, Étude. 
and this probably explains his great influence in this field. Subsequent studies to Waltzing's have not changed his framework ${ }^{11}$.

In this course of their studies, though some scholars conducted research into collegia with respect to the various types ${ }^{12}$, few specific investigations have dealt with activities that were common to all types of collegia. Historical sources identify the following activities of collegia: putting up inscriptions honoring patrons of the collegia, funeral arrangements for deceased members, and holding religious ceremonies and convivial gatherings. Of these activities, the present paper focuses on funeral activities because arrangements surrounding death are thought to be important in studying sociability and mentality ${ }^{13}$. In the following section, after evaluating previous views regarding funeral activities, it will become clear that certain issues remain to be solved.

The first view is one provided by Mommsen in his dissertation. Because of a similar wording in certain legal sources and regulations relating to cultores Dianae et Antinoi $^{14}$, he concluded that there existed collegia funeraticia and that this type of collegia was collectively authorized by the Roman Senate.

11 There are some works in terms of legal history: for example, DE ROBERTIS, F. M., Storia delle corporazioni e del regime associativo nel mondo romano, 2 tomi, Bari, Adriatica editrice, 1971; CRACCORUGGINI, L., "Collegium e corpus: La politica economica nella legislazione e nella prassi”, in: ARCHI, G. G.(ed.), Istituzioni giuridiche e realta politiche nel tardo impero, Milano, A. Giuffre, 1976, pp. 63-94. More recently, there have been some new trends. On scholae (collegial meeting places): BOLLMANN, B., Römische Vereinshäuser, Mainz, Von Zabern, 1998. On the modern scholarship on collegia: PERRY, J. S., The Roman Collegia: the Modern Evolution of an Ancient Concept, Leiden \& Boston, Brill, 2006; DISSEN, M., Römische Kollegien und Deutsche Geschichtswissenschaft im 19. und 20. Jahrhundert, Stuttgart, Franz Steiner Verlag, 2009. On prosopographic studies on collegia's members: ROYDEN, H. L., The Magistrates of the Roman Professional Collegia in Italy from the First to the Third Century A.D., Pisa, Giardini editori e stampatori, 1988; TRAN, N., Les membres des associations romaines: le rang social des collegiati en Italie et en Gaules, sous le Haut-Empire, Rome, École française de Rome, 2006(hereafter, Les membres). On re-evaluation of collegia's economic activities: VERBOVEN, K., "Professional Collegia: Guilds or Social Clubs?", Ancient Society, 41, (2011), pp. 187-195; TRAN, N., "Les collèges professionels romains: «clubs» ou «corporations»?", Ancient Society, 41, (2011), pp. 197-219; BROEKAERT, W., "Partners in Business: Roman Merchants and the Potential Advantages of Being a Collegiatus", Ancient Society, 41, (2011), pp. 221-256; ARNAOUTOGLOU, I., "Craftsmen Associations in Roman Lydia: a Tale of Two Cities?", Ancient Society, 41, (2011), pp. 257-290; GIBBS, M., "Trade Associations in Roman Egypt: Their Raison d'Être", Ancient Society, 41, (2011), pp. 291-315; DIOSONO, F., Collegia: le associazioni professionali nel mond romano, Roma, Edizioni Quasar, 2007.

12 For example, GINESTET, P., Les organisations de la jeunesse dans l'Occident Romain, Bruxelles, Latomus, 1991; VAN NIJF, O. M., "Collegia and Civic Guards: Two Chapters in the History of Sociability", in: JONGMAN, W. \& KLEIJWEGT, M.(eds.), After the Past, Leiden, Boston \& Köln, Brill, 2002, pp.305339; LIU, Jinyu, Collegia Centonariorum: the Guilds of Textile Dealers in the Roman West, Leiden \& Boston, Brill, 2009.

${ }^{13}$ Cf. TOYNBEE, J. M. C., Death and Burial in the Roman World, London, The John Hopkins university, 1971; HOPKINS, K., Death and Renewal, Cambridge, Cambridge University Press, 1983; MORRIS, I., Death-Ritual and Social Structure in Classical Antiquity, Cambridge, Cambridge University Press, 1992.

${ }^{14}$ Dig., XLVII, 22, 1; CIL, XIV, 2112. 
Though his theory received some criticism ${ }^{15}$, it was widely accepted because Waltzing propounded it. Except for his monumental work, Waltzing wrote only one article on collegia, and that article dealt with collegia funeraticia ${ }^{16}$. In the article, he defined collegia as follows: les associations qui se formaient, sous l'Empire, parmi les gens d'humble condition (tenuiores), nés libres, affranchis, ou esclaves, uniquement ou principalement pour procurer à leurs membres un enterrement décent, au moyen d'une caisse alimentée par des cotisations mensuelles. ${ }^{17}$

However, Ausbüttel sharply criticized this theory ${ }^{18}$. He demonstrated that Mommsen had in an arbitrary fashion reconstructed missing parts of inscriptions upon which his theory was based, and Ausbüttel denied the the existence of collegia funeraticia. In addition, Ausbüttel called for the overall significance of funeral activities in collegia to be properly examined. His own analysis of such activities, however, did not go beyond the framework of previous studies.

The author of the present paper believes that funeral activities should be regarded as ones carried out by all collegia, irrespective of type. In this regard, the views of two important scholars have to be considered.

The first is Patterson's. He discussed the problem of burial in the city of Rome through the relationship among patronage, collegia, and family, and he placed a high value on the activities of collegia ${ }^{19}$. However, his examination is incomplete because he did not fully investigate the activities of collegia and his investigation was confined to the city. The other is Perry's. In his dissertation ${ }^{20}$, Perry criticized Mommsen's theory by examining legal sources, and he also insisted that collegia funeraticia did not exist. In addition, Perry exhaustively collected and analyzed inscriptions relating to the funeral activities of collegia. According to him, collegia were needed as a substitute for, or complement to, the family.

Perry's view of collegia as family is very important, and I basically concur with his analysis. However, Perry's examination of the inscriptions was not sufficiently thorough. When examining Type 1 inscriptions (classified below), he focused only on providing commentaries to the inscription texts. However, it is unclear why he regarded collegia as family. Moreover, he did not probe sufficiently the background of collegium members.

${ }^{15}$ SCHIESS, T., Die Römischen Collegia Funeraticia nach den Inschriften, München, Ackermann, 1888; LIEBENAM, W., Zur Geschichte und Organisation des Römischen Vereinswesens, Leipzig, B. G. Teubner, 1890.

${ }^{16}$ WALTZING, J.-P., "Les collèges funéraires chez les romains", Le musée belge, 2, (1898), pp. 281294 \& Le musée belge, 3, (1899), pp. 130-157.

17 Idem., Le musée belge, 2, p.282.

${ }^{18}$ AUSBÜTTEL, F. M., Untersuchungen zu den Vereinen im Westen des Römischen Reiches, Kallmünz, M. Lassleben, 1982.

${ }_{19}$ PATTERSON, J. R., "Patronage, Collegia and Burial in Imperial Rome", in: BASSETT, S.(ed.), Death in Towns: Urban Responses to the Dying and the Dead, 100-1600, Leicester, London \& New York, Leicester University Press, 1992, pp. 15-27; PATTERSON, J. R., "Living and Dying in the City of Rome: Houses and Tombs", COULSTON, J. \& DODGE, H.(eds.), Ancient Rome: the Archaeology of the Eternal City, Oxford, Oxbow Books, 2000, pp. 259-289.

${ }_{20}$ PERRY, J. S., A Death in the Familia: the Funerary Colleges of the Roman Empire, (unpublished Ph.D. thesis), University of North Carolina at Chapel Hill, 1999(hereafter, Death in the Familia). 
The present paper therefore first thoroughly reexamines the inscriptions relating to the funeral activities of collegia based on the catalogs compiled by Waltzing, Schiess, and Perry ${ }^{21}$. It then discusses who joined these groups, why they did so, and what significance they found in collegia. Lastly, it reconsiders the raison d'être of collegia in Roman society.

Before scrutinizing these inscriptions according to their characteristics in subsequent sections, I will classify inscriptions into four types. There are at present 281 inscriptions indicative of funeral activity (however, those of so-called domestic collegia have been excluded ${ }^{22}$ ). Type 1 comprises plain gravestones that were erected solely by collegia for their deceased members; of these, there are 174 examples $^{23}$. Type 2 consists of gravestones that were cooperatively erected by close relatives of the deceased and collegia; of these, there are 40 examples $^{24}$. Type 3 is composed of inscriptions indicating that the graveyards were owned by collegia; of these, there are 63 examples $^{25}$. Type 4 is made up of inscriptions of lex collegii that included rules about funerary activity; of these, there are four examples ${ }^{26}$. These latter four collegia, which had their own regulations, have traditionally been called collegia funeraticia and were as follows: collegium lovis Cerneni, familia Silvani, collegium Aesculapi et Hygiae and cultores Dianae et Antinoi.

${ }^{21}$ WALTZING, Étude, III; SCHIESS, op. cit.; PERRY, Death in the Familia

22 This is because this paper focuses on associations which their members put up or took part in on their free will.

${ }^{23}$ CIL, II, 816; 817; 1293; 1976; 2731; 2732; 3244; 4064; 5500; II-7, 344; III, 1210; 1215; 1501; 1505; 1828; 1829; 3554; 10519; 10540; 5657; 11255; V, 1703; 4122; 4340; 4391; 4395; 4415; 4433; 4501; 4504; 4505; 5283; 5296; 5761; 5854; 5872; 5889; 6492; 7044; VI, 2265; 6220; 6221; 8398; $9004 ; 9036$ 9136; 9316; 9550; 10420; 10423; 20107/8; 22462; 34025; 34027; 37784a; 37843; 37854; VII, 572; VIII, 1878; 9427; 11549; 11592; 12905; 13287; 14608; 15895; 20953; 21071; 21106; 21848; 24686; IX, 459; 460; 496; 939; 1463; 1505; 1687; 1688; 1746; 2480; 2483; 2811; 2964; 3047; 3383; 3447; 3577; 3693; 3740; 3815; 3931; 3960; 3961; 5461; 5906; 6154; X, 24; 142; 143; 174; 340; 370; 528; 1086; 5671; 6699; 7039; 8100; 8107-8109; 8111; 8112; 8339d; 8340b; XI, 629; 1549; 1550; 1555; 1906; 2720-2722; 4749; 5223; 6512; 6523; 6525-6527; 6529; 6533; 6533; 6535; 6538; XII, 286 add.; 732; 734; 736; 5811 add.; 1384; 1914; 2669; 2677; 2824; 3347 add.; XIII, 531; XIV, 2653; 3659; AE, 1898, 144; 1904, 20; 1905, 47; 1906, 108; 1913, 137; 1925, 54; 1937, 140; 1939, 8; 9; 1952, 10; 1964, 134; 1967, 153; 1968, 152; 187 ; 1977, 81; 1980, 422; 1985, 948; 1986, 71; 1999, 1032; ArchClass22(1970)pp.152-163; CRAI (1966) pp. 151-152; (1967) pp. 348-351; Epigraphica17(1955)pp.100-103; IDR, III-2, 406; II, 875; Notizie degli scavi(1943)260.

${ }^{24}$ CIL, II, 379; 3076; 3114; 3229; 5879; III, 1504; 1553; 3583; 10511; V, 337; 1628; 4483; VI, 10681; 12744; 16932; 24601; 33971; 34026; 37852; 37853; IX, 1931 add.; 3526; 4129; 5847; 6320; X, 445; 2072; 8099; 8110; XII, 22; 2459; 2460; 5874; XIII, 2177; Germania(1932)p. 289; Inscriptions de la Mésie Supérieure 6(1982)\#221; \#223; Notizie degli scavi(1902)p.41; Revue archéologique de Narbonnaise 16(1983)pp. 161-169; Studi di Antichità 2(1980)p. $232 f$.

${ }^{25}$ CIL, III, 7807; 11485; ;V, 81; 884; 2590; 2603; 2732; 3351; 3354; 8308; VI, 1946; 4414; 4416; 4417; 9144; 9856; 9888; 10109; 10421; 11034; 11035; 27624; 34004; 34020-22; 33968; IX, 2654; 4673; 5084; X, 4850; 4851; 4853; 4854; 5386; 5647; XI, 1031; 1449; 1530; 4669a; 6135; 6136; 6244; 6310; XII, 1929; 4449; XIII, 645; 913; AE, 1925, 127; 1987, 837; 443; 1993, 1245a; Arheoloski Vestnik 28(1977)pp.399-402; Ephemeris Epigraphica 8, 123-125; Epigraphica 23(1961)pp.8-9; 28(1966)p.189\#20; 44(1982)pp. 201-207; IA, 201; 679; 684; 686; 687.

${ }^{26}$ CIL, III, pp. 924-927; AE, 1929, 161; CIL, VI, 10234; CIL, XIV, 2112. 


\section{GRAVESTONES ERECTED BY COLLEGIA}

I first examine Type 1 inscriptions. Here is an example: $D$ (is) $M$ (anibus). G(aio) Julio Marco, ex colleg(io) fabr(um); vix(it) an(nis) LX; coll(egium) s(upra) s(criptum ${ }^{27}$.

From inscriptions like this, we can identify the names of the deceased member and his collegium. This information enables us to consider the background of the various members and the bonds of the collegia. To begin with, I will attempt to consider this bond through the names of collegia. Could funeral activities be conducted only by some particular sort of collegia? In previous studies, the classification of collegia was based on whether their names referred to the members' occupation or to certain deities. In this paper, I also classify collegia in accordance with this criterion.

Table 1. Names in Type 1 collegia

\begin{tabular}{|l|l|l|l|l|l|}
\hline $\begin{array}{l}\text { name root / } \\
\text { bond }\end{array}$ & professional & religious & others & root only & total (ratio) \\
\hline amici & 1 & 0 & 2 & 2 & $5(3 \%)$ \\
\hline collegium & 37 & 18 & 9 & 18 & $82(53 \%)$ \\
\hline $\begin{array}{l}\text { sodales/so- } \\
\text { dalicium }\end{array}$ & 2 & 4 & 2 & 19 & $27(17 \%)$ \\
\hline $\begin{array}{l}\text { socii/soci- } \\
\text { etas }\end{array}$ & 0 & 0 & 1 & 0 & $1(1 \%)$ \\
\hline others & 12 & 14 & 14 & - & $40(26 \%)$ \\
\hline total (ratio) & $52(34 \%)$ & $36(23 \%)$ & $28(18 \%)$ & $39(25 \%)$ & 155 \\
\hline
\end{tabular}

Table 1 presents the classification results of the names of collegia in Type 1 inscriptions. Though the overall number of Type 1 inscriptions is 174 , the total in Table 1 is 155; this is because the names of some collegia appeared in more than one inscription. The following is the classification procedure: for example, in the case of the name of "collegium fabrum», the name root is "collegium», and "fabrum», indicating the occupation, is added to the root. This collegium is placed into the "collegium» and "professional» category. Collegia whose names lacked a root, such as "lanarii», are placed into the "others» and "professional» category. In the "others» bond category, there are collegia whose bonds are difficult to determine as being professional or religious, such as young men's associations or

\footnotetext{
${ }^{27}$ CIL, III, 1505.
} 
clubs for convivial gatherings, bonds that are thought to be territorial ${ }^{28}$, or where the names are unknown words ${ }^{29}$.

The bonds of the collegia were $34 \%$ «professional», $23 \%$ «religious», $18 \%$ «others», and $25 \%$ «root only.» These figures prove that collegia carried out funeral activities, irrespective of their bonds. Thus, as expressed by Ausbüttel and Perry, it is reasonable and appropriate to regard funeral activities as actions undertaken by all collegia.

Next, to examine the background of collegium members, I will consider the names of the deceased. The naming convention in ancient Rome is known as tria nomina, which consisted of the praenomen, nomen, and cognomen ${ }^{30}$. Of the three names, the nomen and cognomen reflected an individual's background, the more important of the two having been the cognomen. This was because of the procedure about the naming of slaves after they had been manumitted. Slaves usually bore one name as their individual name. However, after they had been freed, they were given names according to the tria nomina: they took their former master's praenomen and nomen as their own praenomen and nomen, and they retained their individual names as the cognomen. So, their cognomen persisted as a vestige of their background as slaves. Analyzing the cognomina of collegium members thus provides powerful clues as to the kind of people that made up the collegium.

The analytical methodology adopted here is as follows. First, find the names of collegium members among the inscriptions; then compare the discovered cognomina with those in the following three works. The first is a name book of slaves in the city of Rome, collected by Solin ${ }^{31}$, in which slaves' names are divided into language categories. Using mainly this collection, I was able to recognize the language category of the names of the collegium members and classify them accordingly. In addition, I was able to decide whether the names were typical of slaves. If I was unable to find the names of collegium members in this collection, I referred to the collection of Greek names in Rome by Solin ${ }^{32}$ and the collection of Latin nomina and cognomina by Solin and Salomies ${ }^{33}$; from these works, I was able to determine which language category to which collegium members' cognomina belonged. Their status indicators and sex were also identified in this manner.

\footnotetext{
${ }^{28}$ For example, CIL, VI, 37852 (sodales viae Lavicanae).

${ }^{29}$ For example, CIL, VIII, 11592 (Barasi).

${ }^{30}$ SALWAY, B., "What's in a Name? A Survey of Roman Onomastic Practice from c.700 B.C. to A.D. 700”, JRS, 84, (1994), pp. 124-145.

${ }^{31}$ SOLIN, H., Die Stadtrömischen Sklavennamen: ein Namenbuch, 3 Bde., Stuttgart, Franz Steiner

${ }^{32}$ SOLIN, H., Die Griechischen Personennamen in Rom: ein Namenbuch, 2. Aufl., 3 Bde., Berlin \& New York, De Gruyter, 2003.

${ }^{33}$ SOLIN, H. \& SALOMIES, O., Repertorium Nominum Gentilium et Cognominum Latinorum, Hildesheim, Zürich \& New York, Olms, 1988.
} Verlag, 1996. 
Table 2. Names of Type 1 collegium members

(A) Cognomina by language (total, 209)

\begin{tabular}{|l|l|l|}
\hline Latin & Greek & others and uncertain \\
\hline 122 & 63 & 24 \\
\hline
\end{tabular}

(B) Number of times the name occurs in Solin (1996)

(total, 187, excluding names of doubtful language category)

\begin{tabular}{|l|l|l|}
\hline 10 or more & fewer than 10 & none \\
\hline 95 & 64 & 28 \\
\hline
\end{tabular}

(C) Status indicator (total, 209)

\begin{tabular}{|l|l|l|l|l|}
\hline citizen & augustalis & freed person & slave & none \\
\hline 14 & 2 & 12 & 12 & 169 \\
\hline
\end{tabular}

(D) Sex

(total, 187, excluding names of doubtful language category)

\begin{tabular}{|l|l|}
\hline male & female \\
\hline 173 & 14 \\
\hline
\end{tabular}

The profiles of Type 1 collegium members are presented in Table 2. As evident in Table 2A, of 209 individuals, 63 had Greek cognomina. Here, it is necessary to consider what kind of people these were-bearing Greek names but living in the western part of the empire. First, they may have been immigrants from the eastern part of the empire. Alternatively, they may have been slaves or ex-slaves, or their lineal relatives may have been slaves, though we cannot determine their origins ${ }^{34}$. If they were not themselves slaves but had slavish origins, it is likely that their fathers or grandfathers were slaves ${ }^{35}$. Consequently, it is plausible that people dwelling in the western part of the empire with Greek cognomina were either im-

${ }^{34}$ FRANK, T., "Race Mixture in the Roman Empire”, AHR, 21, (1916), pp. 689-708; DUFF, A. M., Freedmen in the Early Roman Empire, Oxford, Clarendon Press, 1928, pp. 55-58; GORDON, M. L., "The Nationality of Slaves under the Early Roman Empire", JRS, 14, (1924), pp. 93-111.

35 TAYLOR, L. R., "Freedmen and Freeborn in the Epitaphs of Imperial Rome", AJP, 82, (1961), pp. 113-132. Cf. GARNSEY, P., "Descendants of Freedmen in Local Politics: Some Criteria", in: LEVICK, B.(ed.), The Ancient Historian and His Materials, Farnborough, Gregg, 1975, pp. 167-180. 
migrants from the east or-though their birthplaces cannot be identified-slaves, freed persons, or the close offspring of ex-slaves ${ }^{36}$.

In Table 2B, from the collection of slave names by Solin, I decided whether or not collegium members' names were typical of slaves. I presupposed that if a name occurred more than 10 times in Solin's collection, it was a typical name of slaves in the city of Rome; from this, 95 of the collegium members' names (consisting of 60 Latin, 34 Greek, and one Illyrian name) were typical of slaves. This shows that among collegium members, there were many ex-slaves or the close offspring of ex-slaves who did not have Greek names.

Table $2 \mathrm{C}$ shows that in the cases where the collegium members bore status indicators, about one-third of these denoted slave or ex-slave status. However, none of the elite of Roman society also seems to have been members of collegia.

Therefore, the majority of members of collegia can be considered to have been immigrants from the eastern empire, ex-slaves, or the close offspring of exslaves. Because individuals of equestrian or higher rank were not found and many collegia had professional bonds, the social class of collegium members is likely to have been middle or lower class, but not proletariat. Women could also belong to collegia, though their number was small. The background of collegium members will be closely considered in the Conclusion.

\section{GRAVESTONES ERECTED BY CLOSE RELATIVES OF THE DECEASED AND COLLEGIA}

I now examine Type 2 inscriptions, that is, ones on gravestones cooperatively erected by close relatives of the deceased and collegia. This is an example: Dis Manib(us) N(umeri) Fresidi Successi, decret(o) fabr(um): v(ixit) a(nnis) XIIII, $N$ (umerius) Fresidius Florentinus pat(er) et Fresidia Success(a) mater ${ }^{37}$.

As with Type 1 inscriptions, it is possible to extract two kinds of information (the names of the deceased members and collegia) from such inscriptions. However, even more important is the information as to who made the collaborative effort in putting up gravestones with collegia.

${ }^{36}$ KAJANTO, I., "The Significance of Non-Latin Cognomina", Latomus, 27, (1968), pp. 517-534; MOURITSEN, H., "Freedmen and Decurions: Epitaphs and Social History in Imperial Italy", JRS, 95, (2005), pp. 38-63; MOURITSEN, H., The Freedman in the Roman World, Cambridge, Cambridge University Press, 2011, pp. 124-127.

On immigration: FRIER, W., "Demography", in: $C A H X I^{2}, 2000$, pp. 787-816; SCHEIDEL, W.(ed.), Debating Roman Demography, Leiden, Boston \& Köln, Brill, 2001; SCHEIDEL, W., "Human Mobility in Roman Italy, I: the Free Population", JRS, 94, (2004), pp.1-26; SCHEIDEL, W., "Human Mobility in Roman Italy, II: the Slave Population", JRS, 95, (2005), pp. 64-79. 
Collegia through their funeral activities..

Table 3. Names in Type 2 collegia

\begin{tabular}{|l|l|l|l|l|l|}
\hline $\begin{array}{l}\text { name root / } \\
\text { bond }\end{array}$ & professional & religious & others & root only & total (ratio) \\
\hline amici & 0 & 0 & 0 & 0 & $0(0 \%)$ \\
\hline collegium & 8 & 4 & 3 & 9 & $24(67 \%)$ \\
\hline $\begin{array}{l}\text { sodales/so- } \\
\text { dalicium }\end{array}$ & 0 & 0 & 3 & 4 & $7(19 \%)$ \\
\hline $\begin{array}{l}\text { socii/soci- } \\
\text { etas }\end{array}$ & 0 & 0 & 1 & 0 & $1(3 \%)$ \\
\hline others & 0 & 3 & 1 & - & $4(11 \%)$ \\
\hline total (ratio) & $8(22 \%)$ & $7(20 \%)$ & $8(22 \%)$ & $13(36 \%)$ & 36 \\
\hline
\end{tabular}

Table 3 shows the classification results of the names of collegia in Type 2 inscriptions. Though the overall number of Type 2 inscriptions is 40 , the total in Table 3 is 36; this is because the names of some collegia appeared in more than one inscription. The classification procedure is the same as in Table 1. Compared with the figures in Table 1, the ratio of professional collegia is lower in Table 3; however, the two tables are similar in that there is no divergence among the bond categories.

Analysis of the names of the collegium members covered those of the deceased and individuals who were evidently members. Close relatives of the deceased who erected the tombstones in cooperation with collegia were excluded because it is uncertain whether they were also collegium members.

Table 4. Names of Type 2 collegium members

(A) Cognomina by language (total, 41)

\begin{tabular}{|l|l|l|}
\hline Latin & Greek & others and uncertain \\
\hline 25 & 13 & 3 \\
\hline
\end{tabular}

(B) Number of times the name occurs in Solin (1996)

(total number, 40, excluding names of doubtful language category)

\begin{tabular}{|l|l|l|}
\hline 10 or more & fewer than 10 & none \\
\hline 22 & 12 & 6 \\
\hline
\end{tabular}


(C) Status indicator (total, 41)

\begin{tabular}{|l|l|l|l|l|}
\hline decurio & citizen (?) & freed person & slave & none \\
\hline 1 & 3 & 0 & 2 & 35 \\
\hline
\end{tabular}

*Under categories designated by a question mark, possible indicators are also included.

(D) Sex

(total, 40, excluding names of doubtful language category)

\begin{tabular}{|l|l|}
\hline male & female \\
\hline 32 & 8 \\
\hline
\end{tabular}

The profiles of Type 2 collegium members are presented in Table 4. As evident in Table 4A, of 41 individuals, 13 had Greek cognomina. In Table 4B, the number of cognomina probably typical of slaves is 22 (13 Latin, eight Greek, and one Illyrian name). These proportions are largely similar to those in Table 2. In Table 4C, among the cases where it was possible to identify the status indicator, there was one example of a city councilor. Although this person is not represented as equestrian, he was among the local elite. Other cases confirm the existence of citizens or slave members; however, the majority lacked such indicators. Thus, the background of the members derived from an analysis of the Type 2 inscriptions resembles that with Type 1 inscriptions.

I now present an analysis of the most important information in the Type 2 inscriptions-the relationship between the deceased and the person or persons erecting the funeral monument.

Table 5. Relationship between the deceased and the person(s)erecting the tombstone

\begin{tabular}{|l|l|l|}
\hline relationship & number & ratio* \\
\hline spouse & 10 & $23 \%(27 \%)$ \\
\hline parent & 16 & $36 \%(43 \%)$ \\
\hline grandparent & 2 & $5 \%$ \\
\hline child & 7 & $16 \%(19 \%)$ \\
\hline sibling & 4 & $9 \%(11 \%)$ \\
\hline heir & 1 & $2 \%$ \\
\hline freed person & 2 & $5 \%$ \\
\hline friend & 1 & $2 \%$ \\
\hline publicly & 1 & $2 \%$ \\
\hline
\end{tabular}

* The numbers within parentheses are the ratios within nuclear family relationships 
The result of this classification appears in Table 5. Among the 40 examples, there were inscriptions on four gravestones that had each been erected by two people who bore different relationships to the deceased ${ }^{38}$. In these cases, the four people involved were counted separately; thus, the total number of examples amounts to 44 . Cases of a parent putting up a tombstone for their child accounted for $36 \%$, which is the highest proportion; in $23 \%$ of cases, the gravestone was erected by a spouse; a child put up a tombstone for a parent in $16 \%$ of cases. It is important to compare these figures with those in a study by Saller and Shaw ${ }^{39}$. According to their study, about $80 \%$ of the funeral monuments of urban dwellers were erected by people within the nuclear family. As Table 5 indicates, cases of spouses, parents, children, and siblings amounted to $84 \%$, a figure that is consistent with the data of Saller and Shaw. However, there is a marked difference between the results of the present study and those of Saller and Shaw when the proportions of spouses, parents, children, and siblings are analyzed separately. According to their findings, spouses accounted for $38 \%$, parents $31 \%$, children $22 \%$, and siblings $9 \%{ }^{40}$. However, in the present study, spouses accounted for $27 \%$ and parents $43 \%$. What significance do these differences have with regard to the membership of collegia or the social importance of these groups?

In studies of Roman gravestones, it is generally recognized that when children-especially small children-pass away, parents who are freed persons are most likely to be the ones to set up the gravestones ${ }^{41}$. A possible explanation for the findings in this study is that freed persons are more eager to set up tombstones for their children because this was a means of widely demonstrating that they had acquired citizenship ${ }^{42}$. Through the medium of gravestone, freed individuals would have had the greatest chance to advertise their citizenship.

Conversely, the higher proportion of parents setting up tombstones for their children signifies that many freed citizens belonged to collegia. In addition, the fact that this important act was undertaken with collegia points to the close relationship that must have existed between families and collegia. There may have been a feeling that families depended on collegia for a greater bond for the deceased-one that also embraced the family bond.

${ }^{37}$ CIL, IX, 5847.

${ }^{38}$ CIL, V, 4483 (a grandfather and a friend); CIL, III, 1553 (a child and a sibling); CIL, VI, 10681 (a spouse and a sibling); CIL, VI, 37852 (a grandmother and a parent).

${ }^{39}$ SALLER \& SHAW, op. cit.

40 Idem., Tables 4-16, pp. 147-150.

${ }^{41}$ For example, NIELSEN, H. S., "Interpreting Epithets in Roman Epitaphs", in: RAWSON, B. \& WEAVER, P.(eds.), The Roman Family in Italy: Status, Sentiment, Space, Oxford \& New York, Oxford University Press, 1997, p.203.

42 Cf. KING, M., "Commemoration of Infants on Roman Funerary Inscriptions", in: OLIVER, G. J.(ed.), The Epigraphy of Death: Studies in the History and Society of Greece and Rome, Liverpool, Liverpool University Press, 2000, pp. 117-154; MCWILLIAM, J., "Children among the Dead: the Influence of Urban Life on the Commemoration of Children on Tombstone Inscriptions", in: DIXON, S.(ed.), Childhood, Class and Kin in the Roman World, London \& New York, Routledge, 2001, pp. 74-98; MOURITSEN, The Freedman in the Roman World, pp. 127-128. 


\section{GRAVEYARDS OWNED BY COLLEGIA}

I now examine Type 3 inscriptions. These inscriptions were generally erected at the graveyards of collegia, and the inscription confirmed that the graveyard was owned by some collegium. Most of the inscriptions are brief, but some of them contain keys to understanding characteristic features of the collegia. Here are two such inscriptions: $L$ (ucius) Cincius $L$ (uci) f(ilius) Sub(urana tribu) Martialis ... possessor hujus monumenti ... decuriae (decimae) collegium fabrum tignuariorum parietem dextrum introitus ollas XXXII, eis qui infra scripti sunt singulis singulas [the list of 22 inscribed members] Reliquas ollas (decem), qui in hac decuria allecti erint, singulas do lego... ${ }^{43}$; G(aius) Petronius Mantes, aurifex, decurio Mut(inae), aurificibus et conjugibus eorum, et (iis) qui inter nos sunt, locum long(um) p. XXVI, lat(um) p. XVI ... de suo dedit ${ }^{44}$.

From the above two inscriptions, the persons who would have held a leading position in each collegium provided its members with a place for the storage of cinerary urns or a cemetery. We can infer closeness among the members of the collegium from the wording in the inscriptions. The phrase "conjugibus eorum, et (iis) qui inter nos sunt" shows that the closeness was not limited to the collegium members but also extended from the collegium to the families. Conversely, in the phrase "qui in hac decuria allecti erint» 45 , the use of the future perfect tense suggests that the members of this collegium had already decided what people they would accept as members. These inscriptions thus reflect both the closeness within collegia and their closed nature to outsiders.

As with Type 1 and Type 2, I here analyze the names of the collegia and their members with Type 3 inscriptions.

Table 6. Names in Type 3 collegia

\begin{tabular}{|c|c|c|c|c|c|}
\hline $\begin{array}{l}\text { name root / } \\
\text { bond }\end{array}$ & professional & religious & others & root only & total (ratio) \\
\hline amici & 0 & 2 & 1 & 0 & $3(5 \%)$ \\
\hline collegium & 10 & 0 & 2 & 1 & $13(22 \%)$ \\
\hline $\begin{array}{l}\text { sodales/so- } \\
\text { dalicium }\end{array}$ & 1 & 0 & 0 & 1 & $2(3 \%)$ \\
\hline $\begin{array}{l}\text { socii/soci- } \\
\text { etas }\end{array}$ & 3 & 0 & 3 & 4 & 10 (17\%) \\
\hline others & 7 & 14 & 10 & - & 31 (53\%) \\
\hline total (ratio) & 21 (36\%) & $16(27 \%)$ & $16(27 \%)$ & $6(10 \%)$ & 59 \\
\hline
\end{tabular}

${ }^{43}$ CIL, VI, 9405.

${ }^{44}$ Epigraphica 28(1966), p.189(\#20).

45 The word 'erint' is likely to have been cacography (correctly, 'erunt'). 
Table 6 shows the classification results of the names of collegia in Type 3 inscriptions. Though the overall number of Type 3 inscriptions is 63, the total in Table 6 is 59; this is because the names of some collegia appeared in more than one inscription. The classification procedure is the same as in Tables 1 and 3 . Compared with the figures in Tables 1 and 3 , the ratio of collegia whose names consisted only of roots is lower in Table 6 . This is because the names of more than half of the collegia in Type 3 inscriptions did not have name roots and were represented only by plural forms of the nouns standing for their bonds. It is possible that it was advantageous with Type 3 inscriptions to render the names of the collegia in this way. In any event, there is no divergence from Tables 1 and 3 in terms of the bond categories.

Table 7. Names of Type 3 collegium members

(A) Cognomina by language (total, 338)

\begin{tabular}{|l|l|l|}
\hline Latin & Greek & others and uncertain \\
\hline 208 & 115 & 15 \\
\hline
\end{tabular}

(B) Number of times the name occurs in Solin (1996)

(total, 325, excluding names of doubtful language category)

\begin{tabular}{|l|l|l|}
\hline 10 or more & fewer than 10 & none \\
\hline 191 & 97 & 37 \\
\hline
\end{tabular}

(C) Status indicator (total, 338)

\begin{tabular}{|l|l|l|l|l|l|}
\hline decurio & citizen (?) & augustalis & freed person & slave (?) & none \\
\hline 2 & 16 & 10 & 43 & 1 & 266 \\
\hline
\end{tabular}

*Under categories designated by a question mark, possible indicators are also included.

(D) Sex

(total, 325, excluding names of doubtful language category)

\begin{tabular}{|l|l|}
\hline male & female \\
\hline 284 & 41 \\
\hline
\end{tabular}


The profiles of Type 3 collegium members are presented in Table 7. In Table 7A, of 338 individuals, 115 had Greek cognomina. As seen in Table 7B, the number of cognomina probably typical of slaves is 191 (117 Latin and 74 Greek names). This proportion is largely similar to those in Tables 2 and 4 . In Table 7C, I found two examples of a city councilor and 10 examples of an augustalis. This number of augustales is remarkable, but it is not a feature of Type 3 collegia as a whole because such augustales belonged to the same collegium ${ }^{46}$. Other cases confirm the existence of citizen, freed, and slave members, but the majority of inscriptions lacked such indicators. Thus, the background of the members gained from an analysis of Type 3 inscriptions can be regarded as similar to that with Types 1 and 2 .

\section{LEGES COLLEGII}

Lastly, I examine Type 4 inscriptions, which contain the inscriptions of collegia conventionally called collegia funeraticia. Of the collegia that are the subject of this paper, it is only through these Type 4 collegia that it is possible to learn of any activity except that pertaining to the funeral. Therefore, this section explores the regulations of these collegia (or leges), and it examines collegia from a different perspective to that of quantitative analysis.

Type 4 inscriptions consist of four very informative examples, and so all the inscriptions need to be studied in detail. However, because of space constraints, I will confine myself to pointing out the more remarkable aspects that fit in with the purpose of this paper. I will examine two collegia-familia Silvani and collegium Aesculapi et Hygiae ${ }^{47}$

The first case is that of familia Silvanit8. This inscription was found near Reate (now Rieti) in central Italy, and it was a dedicative inscription set up in AD 60. It includes a list of the members of this collegium, and I will conduct an analysis of the names of these members using the previous procedure.

\section{Table 8. Names of members of Familia silvanis}

(A) Cognomina by language (total, 80)

\begin{tabular}{|l|l|l|}
\hline Latin & Greek & others and uncertain \\
\hline 58 & 19 & 3 \\
\hline
\end{tabular}

${ }^{46}$ Eph. Epigr., VIII, \#224. Cf. BUONOCORE, M., "Ricerca onomastica su un collegium funeraticium di Chieti", Settima miscellanea greca e romana, (1980), pp. 429-446.

${ }^{47}$ Cf. FLAMBARD, J.-M., "Éléments pour une approche financière de la mort dans les classes populaires du Haut-Empire: Analyse du budget de quelques collèges funéraires de Rome et d'Italie", in : HINARD, F.(éd.), La mort les morts et l'au-delà dans le monde romain, Caen, Centre de publ. de l'Universite de Caen, 1987, pp. 209-244. 
Collegia through their funeral activities...

(B) Number of times the name occurs in Solin (1996)

(total, 78, excluding names of doubtful language category)

\begin{tabular}{|l|l|l|}
\hline 10 or more & fewer than 10 & none \\
\hline 53 & 21 & 4 \\
\hline
\end{tabular}

The profiles of Type 4 collegium members are presented in Table 8 . In all, 78 members appear on the list; the names of three members appear elsewhere in the inscription. One of those three members, however, also appears on the list; thus, the total number of the members is 80 . Of that number, 19 had Greek cognomina. The number of the cognomina that are probably typical of slaves is 53 (45 Latin, seven Greek, and one Illyrian name). Compared with the proportions in Tables 2, 4, and 7, this proportion of Greek cognomina is rather low. Was it because this collegium was composed mostly of Latin people and had not been affected by such great changes as immigration from the eastern part of the empire?

However, in terms of the status indicators, a completely different picture emerges with this collegium. Unlike the members of other collegia, those on the list bear their tribus. A clue to understanding the background of people at that time can be gained from the tribus to which they were assigned. With this collegium, 26 members carry their tribus names, and they are all Collina or Quirina. These are the tribus to which immigrants from the eastern part of the empire were assigned during the imperial period ${ }^{49}$. If members with Latin cognomina but these tribus names are considered Greek together with the members having Greek cognomina but no tribus name, 40 members are identified as being of Greek origin and 37 of Latin origin.

I now proceed with the regulations of familia Silvani:

Lex familiae Silvan(i) ... cum ad sacrum ventum erit nequis litiget neve rixam faciat neve extraneum invitet ea die si ita fecerit d(are) d(ebeat) HS XX qui ex ea familia decesserit ut ei conferant singuli HS VIII nequis decumanis moram faciat plus triduo qui ita fecerit aut exequias non fuerit nisi certa causa d(are) d(ebeat) HS XX ex cuius decuria deliquerit eorum cura erit tollere si ita non fecerit d(are) d(ebeat) $H S X$...

First, there are the regulations prohibiting members from inviting outsiders to feasts. For members being unable to bring outsiders to feasts signifies both closeness within the collegium and a closed nature to others. As I indicated with respect to Type 3 inscriptions, collegia offered opportunities for the members to mingle closely with each other, but they also tended to exclude outsiders. Second, ac-

${ }^{48} A E, 1929,161$.

${ }^{49} O C D^{3}$, s. v. tribus(by A. MOMIGLIANO \& T. J. CORNELL); TAYLOR, L. R., The Voting Districts of the Roman Republic, Rome, American Academy, 1960, pp. 147-149. 
cording to the regulations with respect to funeral activities, members who failed to fulfill their obligations to make funeral arrangements and to attend a funeral were punished. These regulations reflect this collegium's emphasis on funeral activities as its main business.

The second case to examine is that of collegium Aesculapi et Hygiae ${ }^{50}$. This inscription was found in the city of Rome. On this inscription appear details of a donation made by an individual to this collegium and the conditions relating to it. These conditions were made in AD 153, and it is likely that the collegium was established shortly before this.

Lex collegi Aesculapi et Hygiae ... Item eadem Marcellina collegios(upra)s(cripto) dedit donavitque (sestertium quinquaginta) m(ilia) n(ummum) hominibus n(umero sexaginta) sub hac condicione, ut ne plures adlegantur quam numerius s(upra) s(criptus), et ut in locum defunctorum loca veniant, et liberi adlegantur, vel si quis locum suum legare volet filio vel fratri vel liberto dumtaxant. ut inferat arkae n(ostrae) partem dimidiam funeratici, et ne eam pecuniam s(upra) s(criptam) velint in alios usus convertere, sed ut ex usuris ejus summae diebus infra scriptis locum confrequentarent.

In the opening sentences, it is explained that Marcellina donated a building, land, and money to this collegium in honor and memory of her late husband. Most remarkable are the conditions concerning the use of the money. For the donation to be made, she stipulated that there be a limit to the number of collegium members. Because this inscription was set up in a public place, many people would have come to know about the collegium. Nevertheless, a limit on the number of members was required, and-as in the cases of Type 3 inscriptions and familia Silvani-this underlines its closed nature. Of course, the reason for the limit may have been financial. But though the collegium limited the number of its members, it did take charge of the burial of the families and freed slaves of its members. If the reason for the limit was purely financial, the collegium could have limited the numbers of the members' families or freed slaves that it attended to. However, there were no such limitations. Therefore, it is much less likely that the collegium limited its membership for financial reasons.

Item VIII k(alendas) Mart(ias) die karae cognationis ad Martis eodem loco dividerent sportulas oane $(m)$ et vinum, sicut $s$ (upra) $s$ (criptum) est prid(ie) non(as) Nov(embres) ... Item V id(us) Mai(as) die rosae eodem loco praesentibus dividerentur sportulae vino et pane sicut diebus s(upra) s(criptis) ...

This describes the schedule for a feast, which is interesting. The festival of Caristia and the Day of Roses were both festivals deeply connected with families and relatives ${ }^{51}$. The former was celebrated after the festival of Parentalia, which

${ }^{50}$ CIL, VI, 10234.

${ }^{51}$ HARMON, D.P., "The Family Festivals of Rome", ANRW, 16-2, (1978), pp. 1592-1603; DIXON, S., The Roman Family, Baltimore \& London, Johns Hopkins University Press, 1992, pp. 133-138. 
was celebrated from 13 to 21 February. The festival of Parentalia was one in which people mourned their ancestors' souls. And the festival of Caristia was one for citizens to affirm their ties among family or relatives by enjoying a meal. The Day of Roses took place on 11 May, which was during the festival of Lemuria, celebrated from 9 to 13 May. This period was a time that people were supposed to spend with their families and relatives. Why were the members of this collegium scheduled to make feasts during these festivals? In the next section, I will attempt to answer this question.

\section{CONCLUSION}

Here, I make some general remarks regarding this paper's analyses. First, I bring together the analyses of the names of the collegia and members of all the types.

Table 9. Names in all collegia

\begin{tabular}{|l|l|l|l|l|l|}
\hline $\begin{array}{l}\text { name root / } \\
\text { bond }\end{array}$ & professional & religious & others & root only & total (ratio) \\
\hline amici & 1 & 2 & 3 & 2 & $8(3 \%)$ \\
\hline collegium & 55 & 24 & 14 & 28 & $121(48 \%)$ \\
\hline $\begin{array}{l}\text { sodales/so- } \\
\text { dalicium }\end{array}$ & 3 & 4 & 5 & 24 & $36(14 \%)$ \\
\hline $\begin{array}{l}\text { socii/soci- } \\
\text { etas }\end{array}$ & 3 & 0 & 5 & 4 & $12(5 \%)$ \\
\hline others & 19 & 32 & 25 & - & $76(30 \%)$ \\
\hline total (ratio) & $81(32 \%)$ & $62(24.5 \%)$ & $52(20.5 \%)$ & $58(23 \%)$ & 253 \\
\hline
\end{tabular}

Table 9 shows the classification results of the names of collegia of all types of inscriptions. Of the 281 examples, cases of overlapping data have been deleted, and so the total number in Table 9 is 253. As noted earlier, there was no divergence among the bond categories. Therefore, at least in terms of the bonds within collegia, it is reasonable and appropriate to consider funeral activities as being conducted by all collegia.

I will now summarize the analyses of the names of the collegium members.

Table 10. Names of all collegia

(A) Cognomina by language (total, 679)

\begin{tabular}{|l|l|l|}
\hline Latin & Greek & others and uncertain \\
\hline 417 & 216 & 46 \\
\hline
\end{tabular}


(B) Number of times the name occurs in Solin (1996)

(total, 640, excluding names of doubtful language category)

\begin{tabular}{|l|l|l|}
\hline 10 or more & fewer than 10 & none \\
\hline 367 & 198 & 75 \\
\hline
\end{tabular}

(C) Status indicator (total, 679)

\begin{tabular}{|l|l|l|l|l|l|}
\hline decurio & citizen (?) & augustalis & freed person & slave (?) & none \\
\hline 3 & 59 & 12 & 58 & 15 & 532 \\
\hline
\end{tabular}

(D) Sex

(total, 640, excluding names of doubtful language category)

\begin{tabular}{|l|l|}
\hline male & female \\
\hline 576 & 64 \\
\hline
\end{tabular}

The profiles of all collegium members are presented in Table 10. This includes the profiles of Type 1, 2, 3, and 4 inscriptions. As seen in Table 10A, of the total 679 individuals, 216 had Greek cognomina. These may have been immigrants from the eastern part of the empire. Alternatively, they may have been slaves or exslaves, or their lineal relatives may have been slaves, though we cannot ascertain their origins.

As is evident in Table 10B, 367 members had the typical cognomina of slaves. These 367 members consisted of 235 Latin, 129 Greek, and three Illyrian names. From this, it is probable that among collegium members who did not have Greek names were many ex-slaves or the close offspring of ex-slaves.

Therefore, regarding the status or origin of members, together with the considerations regarding Table 5, we can be fairly certain that immigrants from the east and former slaves or close direct descendants of slaves accounted for about $70 \%$ of all collegium members ${ }^{52}$. With respect to social class, they were below the equestrian order. Because the membership rates for professional collegia were higher and some Type 4 collegia collected membership fees, the members were probably not in the unpropertied class but in the middle or lower class of city dwellers ${ }^{53}$.

52 (216(carrying Greek cognomina)+235(carrying Latin cognomina typical of slaves))/679(the total individuals) $=0.67$

${ }^{53}$ This view of the status or origin of members is different from the view which $\mathrm{N}$. Tran presents in his monograph(TRAN, Les membres). This is probably because of the difference between collegia each view is based on. 
What significance did collegia have for their members? The gravestones that were erected by close relatives of the deceased (that is, Type 2 inscriptions) made up approximately $18 \%$ of all the gravestones (that is, Type 1 and 2 inscriptions). However, Saller and Shaw pointed out that in the case of the civilian population, tombstones built by the family of the deceased constituted about $80 \%$ of the total. There is a major discrepancy between these two figures. From this, it would appear likely that the people who became members of collegia had lost links with their families or other relations because they had been liberated from slavery or had immigrated from the east.

In addition, the examination of the wording of the leges collegii inscription shows that some collegia collectively celebrated festivals that would ordinarily have been celebrated among families or other relatives ${ }^{54}$. Other collegia had magistrates named pater or mater-father or mother ${ }^{55}$. There was also a close relationship between family and funerary activity in Roman law ${ }^{56}$. From the above, we can conclude that collegia became the means by which members could obtain quasi-family relationships.

In section 1, I stated that I basically agree with Perry's view. However, there are crucial differences between my view and Perry's with respect to the grounds for considering collegia as family and its significance.

Perry based his view on cases of Type 2 and 3 inscriptions. He argued that because collegia set up gravestones in cooperation with the dead members' family and because some members were buried at the same cemetery, collegia had familial functions. He did not, though, analyze the background of the collegium members, and he made the tacit assumption that the members of collegia had families in the normal sense of the word. Yet as this paper has demonstrated, through carrying out funeral activities, making feasts, and celebrating family festivals, collegia offered opportunities for the members, most of whom had lost their familial bonds, to acquire quasi-family.

Finally, I would like to place this conclusion in the broader context of Roman society. Perry criticized theories that maintained that Roman households were rather small ${ }^{57}$. This point is of course important, though discussing Roman families in terms of household sizes runs the risk of descending into a never-ending cycle. Instead of discussing the size of households, it is more the mentality of ordinary Roman people that we should infer from considerations of collegia as family.

An interesting suggestion has been made with regard to the significance of the family for ordinary people ${ }^{58}$. According to this, the relationship of marriage, not con-

${ }^{54} \mathrm{Cf}$. Inscriptiones Aquileiae, 2873(Though not directly relating to the funeral activities of collegia, this inscription of collegium shows feast arrangements similar to those of collegium Aesculapi et Hygiae).

55 PERRY, Death in the Familia, pp. 178-92

${ }^{56}$ Dig., XI, 7.

${ }^{57}$ PERRY, Death in the Familia, pp. 160-174.

${ }^{58}$ MOTOMURA, R., "Sex' and Families in the Roman Empire", in: Yuge, T. \& ITO, S.(eds.), Greece and Rome: Comparative Studies of Antiquity(in Japanese), Tokyo, Kawade Shobo Shinsha, 1988, pp. 275-300. 
cubinage-especially among slaves and soldiers-was something that began to be desired from the days of the early empire, particularly from the late second century. Clearly, we cannot view marriage as being identical with family, but I believe that these two phenomena have something in common. That is, during the Principate, ordinary people developed the sense that a stable family is what they should aim toward as their basic status. Such a sense would have encouraged legal marriage on the one hand and collegia as quasi-families on the other. From the arguments presented in this paper, we can identify such changes in the mentality of ordinary people in Roman society. 